\author{
Marquette University \\ e-Publications@Marquette
}

\title{
The Postfeminist Filmic Female Gothic Detective: Reading the Bodily Text in Candyman
}

Diane Hoeveler

Marquette University, diane.hoeveler@marquette.edu

Follow this and additional works at: https://epublications.marquette.edu/english_fac

Part of the English Language and Literature Commons

\section{Recommended Citation}

Hoeveler, Diane, "The Postfeminist Filmic Female Gothic Detective: Reading the Bodily Text in Candyman" (2007). English Faculty Research and Publications. 256.

https://epublications.marquette.edu/english_fac/256 


\section{"The Postfeminist Filmic Female Gothic Detective: Reading the Bodily Text in Candyman and Gothika"}

\section{Diane Long Hoeveler}

\section{I. “Sadism demands a story."-Laura Mulvey}

In an essay published almost 20 years ago, "When the Woman Looks," Linda Williams asks what happens when women view horror films, and she observes that "the female look-a look given preeminent position in the horror film—shares the male fear of the monster's freakishness, but also recognizes the sense in which this freakishness is similar to her own difference"(87-88). In other words, when a woman looks at a black or monstrous male body, she recognizes her own socially constructed sense of bodily deformity and freakishness. Projection, introjection, cannibalization, and identification — such have been the psychic contortions that have characterized women as subjects and objects in contemporary American horror films. This essay examines the evolution of the filmic female gothic detective in Clive Barker's short story The Forbidden (1985), the literary source for the first two Candyman films (1992; 1995), as well as her most recent hybridized reincarnation in the film Gothika (2003). Doing so will allow us to focus specifically on the woman's pursuit of the meaning and identity of the monstrous black male body that eerily begins to resemble her own.

To begin: I would claim that both Candyman films suggest that the dominant culture has a strong investment in a racial hierarchy, and in asserting the supremacy of Whiteness, the dominance of White masculinity, and that both of them play with the tropes used much earlier in Birth of a Nation or King Kong: the ritual sacrifice of a virgin to a black potent male, the "brutal 
Black buck." As such, both films have to be recognized as replicating in their very tropes the stereotypes that they appear to be trying to critique. ${ }^{1}$ In focusing on the female gothic detective, however, both films actively position and reify the power of the female gaze against the sexual violence inherent in the black male body while also focusing on the destructive heritage that this male body has both caused and suffered. In other words, the black male body is split between being portrayed as both a victim and a victimizer of White male violence, just as the female body traditionally has been bifurcated in the many virgin/whore depictions of women in Western cultural works.

There are many graphic and grotesque murder scenes in Bernard Rose's first Candyman film (1992), some so bloody and garish that viewers are forced to cover their eyes out of sheer self-protection. But if one's tastes run to the more psychologically complex forms of terror, perhaps the most frightening scene in the first Candyman film occurs in the parking lot when the heroine is accosted by the ominous and ruggedly handsome black man, known as the Candyman, who pins her against her car and sneers, "be my victim." What is most horrific about the demand is not simply its baldness, its sheer blunt, brazen, unsubtle wording, but instead what grips the viewer (at least this female viewer) is the heroine's eyes, the combination in them of willingness and fear, desire and loathing. The film, in other words, ostensibly presents a black male's attempt to seize the power of the gaze, to seize the meaning of the narrative for himself, to make the film about him, his erotic pain and history. The white woman as academic researcher and female gothic detective, however, gazes back in such a dominating manner that instead she appears to take control of the gaze. Effectively, she turns the black man into the castrated object of the film's - and her-visual desire. But both are destroyed by the conclusion of the first film and the 
story on which both the films are based. In fact, examining what I would call the nexus of Candyman texts reveals how difficult it is to tell anything but thoroughly sexist, racist, and classist narratives, even when the authors are well-intentioned liberals who ostensibly want to expose those very crimes in their works. What this nexus of texts reveals, finally, is the power of the sheer negative weight of ideologies about white women and black men.

In her classic essay "Visual Pleasure and Narrative Cinema” (1975), Laura Mulvey has theorized that Hollywood cinema has succeeded so spectacularly because it has constructed a series of patriarchal and sexist visual codes that produce the fantasy that the white male subject is not essentially a fragmented being but instead possesses an imaginary unified ego, thereby giving rise to his erotic and sublimated pleasure. Male hegemony, in other words, is built on the back of those fragmented beings — women and minorities — whose subjectivity is effaced so that the white male viewer can experience himself and his world as unitary (432). Film, she argues, functions as "the unconscious of patriarchal society," while "phallocentrism in all its manifestations depends on the image of the castrated woman to give order and meaning to its world" (432). For Mulvey, the castrated woman can transcend her "lack" only through the production and visual display/ presentation of a child, the vehicle through which she can enter, however tenuously, the realm of the symbolic: "she turns her child into the signifier of her own desire to possess a penis....Either she must gracefully give way to the word, the name of the father and the law, or else struggle to keep her child down with her in the half-light of the imaginary" (432-3). Keep that image of "half-light" in mind as we discuss the woman and child who enter the inferno at the conclusion of Clive Barker's story The Forbidden, and its first filmic adaptation, with only the child escaping in the film version and the heroine going up in flames as a sacrifice to the patriarchal order. The 
childless female gothic detective in league with a sacrificial virgin also functions throughout Gothika, again suggesting that women who crack the codes of the patriarchy do so at the expense of their bodies.

In addition to a fairly standard Lacanian approach, Mulvey's analysis neatly posits two modes of looking at film: (1) identificatory voyeurism based on sexual drives or (2) gazing based on narcissism and controlled by ego instincts. Then she notes that for male viewers there are only two ways to escape the castration anxiety provoked by gazing on the woman's sexual difference: demystifying her mystery and saving her (as in film noir) or overvaluing and fetishizing her (as in star vehicles and cults, 438). As she notes, "sadism demands a story[; it] depends on making something happen, forcing a change in another person, a battle of will and strength, victory/defeat, all occurring in a linear time with a beginning and an end" (438). Mulvey advocates in place of this sexist monopoly a "new language of desire that would disrupt the pleasure of a male gaze directed at a female object." This new "language of desire" would be known instead as a "female gaze," and presumably would reverse patriarchal and sexist visual imagery with egalitarian tropes that would please women viewers.

But Mulvey's pat formula has not gone without challenge, and many recent film critics have complicated our understanding of how women view film, and indeed how they read texts. ${ }^{2}$ Mary Ann Doane has, for instance, attempted to use Joan Riviere's theory of "feminine masquerade" to explain the female gaze: "what might it mean [for a woman] to masquerade as spectator?...to assume the mask in order to see in a different way?" (82). She goes on to note that the female spectator of film is given two options: "the masochism of over-identification and the narcissism of becoming one's own object of desire, in assuming the image in the most radical 
way. The effectivity of the masquerade lies precisely in its potential to manufacture a distance from the image, to generate a problematic within which the image is manipulable, producible and readable by the woman" (87). It seems fair to say that a certain sadism as well as masochism permeates the presentation of women in horror films, but the same is true of the fetishizing of people of color. What happens, however, when a white woman and a black man vie for the status of legitimate victim in literature and its ideological helpmate, film? This essay will attempt to address that question by focusing alternately on the figure of the white female detective and her demonized alter-ego, the tortured black male body, in the first two Candyman films (based on Clive Barker's short story The Forbidden) as well as Gothika.

\section{II: "She fought to resist the rapture, though. There was a monster here." Clive Barker, "The Forbidden"}

When Clive Barker published his story The Forbidden in 1985, he set the action in a public housing project in Liverpool - the Spector Street Estate-inhabited by lower-class white residents in urban England. And note the name of the development-Spector - these are lowerclass people who are not allowed to look at themselves and hence are powerless to transform their economic and social situations. Instead, they are the objects of study for others. Or, even worse, they are transfixed and held in the grip of a spectre, the evil presence they name Candyman out of a mixture of irony and desperation. Further, they are the objects of futile speculation by others, like Helen, the white academic researcher who cannot improve their lot but only puzzle about it as a subject for her thesis. Barker's political agenda is clearly liberal, as he presents a dehumanizing concrete block hell in which hundreds of poor white people are forced to live, like so many drones 
in a capitalistic machine-hive. The story The Forbidden had for Barker an original and specific political purpose: to reveal the class prejudice and institutionalized poverty that permeated and polluted British society. Barker and his later film collaborators revised and recast this story in two American filmic adaptations, both of which moved the focus away from white lower-class Britons to the more relevant topic for American audiences: the continued traumatic effects of miscegenation and slavery in the United States.

In Barker's story his heroine, Helen Buchanan, is engaged in writing a thesis on the subjects of sociology and aesthetics, "Graffiti: the semiotics of urban despair," a rather trite subject as her professor husband, Trevor, informs her. But Helen has grandiose ambitions; she seeks nothing less than the discovery of "some unifying convention...the lynch-pin of her thesis" (2). What Helen discovers is a large head painted around a door, so that the door functioned as the head's mouth and in order to enter the room, people were forced to step through the mouth as if into the figure's head. Scrawled around the head was the phrase, "Sweets to the sweet" (7). But before Helen can make any sense out of the cliché, she is informed that there is a murderer in the complex, and that one of his most recent victims was an old man who was found cut to pieces, with his eyes sliced out (9). Lest we miss the blatant castration imagery here, we are next informed via some local women that another of the recent victims is a retarded man who had been attacked in a public toilet: "“and they'd cut off his private parts. Just cut them off and flushed them down a toilet. No reason earth to do it"' (15). But in any discourse system ultimately concerned with male potency and threats to it from women and black men in particular there is every reason to "do it."

Being a contemporary version of the female gothic detective, Helen employs these tales 
of mutilation and horror as dinner party conversation with her insufferably unfaithful and aloof husband and his gay colleague-rival, Archie Purcell, who condescendingly dismisses them as variations on an old gothic staple, the bleeding nun narrative, which he describes in modern dress form: “"What about the lovers and the escaped lunatic....the lover is disemboweled—usually by a hook-handed man —and the body left on the top of the car, while the fiancé cowers inside."” As Archie notes, this staple of folklore is actually a " "cautionary tale, warning of the evils of rampant heterosexuality"' (18). Helen presses Archie on the sheer prevalence of the tales, and finally he concludes that such persistence suggests that the subject of sudden and violent death "“is simply taboo material,"” and another guest chimes in, “maybe just that death has to be near; we have to know it's just round the corner. The television's not intimate enough"' (19). Nor, presumably, are films. And later when Helen is informed by a police detective that the murders and mutilations had never occurred, she muses "was there a place, however small, reserved in every heart for the monstrous?" (28). Barker would, I think, answer in the affirmative.

In the Barker story, Candyman is a mysterious force of evil who demands the periodic sacrifice of small children to stave off his murderous attacks on the inhabitants of a lower-class housing project. Everyone in the story is white, and race never figures in the text's production of horror, however, death does. For some inexplicable reason, a young mother has allowed her baby to be this year's sacrifice and Helen stumbles on the dead baby while hunting for the source of murder and mayhem in the complex. When Helen finally confronts the Candyman in his lair she finds him wrapped in a cloak that conceals razor blades as well as candies. He is every child's imagining of the bogeyman come to life, the stranger who lures you with candy only to slash your throat and possibly drink your blood. And such a scenario seems, in fact, to be operative, for 
Helen finds Candyman with the dead and mutilated baby at his feet, and she describes him as a cross between the Frankenstein monster and Dracula, with something of the risen Christ thrown in for ironic measure:

He was bright to the point of gaudiness: his flesh a waxy yellow, his thin lips pale blue, his wild eyes glittering as if their irises were set with rubies. His jacket was a patchwork, his trousers the same. He looked, she thought, almost ridiculous, with his blood-stained motley, and the hint of rouge on his jaundiced cheeks. But people were facile. They needed these shows and shams to keep their interest. Miracles; murders; demons driven out and stones rolled from tombs. The cheap glamour did not taint the sense beneath. It was only, in the natural history of the mind, the bright feathers that drew the species to mate with its secret self. (32)

In this final climatic confrontation between Helen and Candyman, he asks her if she believes in him, as if he were some sort of a god. Next he asks her why she wants to continue living if she admits his existence: “'Be my victim....I won’t force it upon you. I won’t oblige you to die. But think; think. If I kill you here - if I unhook you,- - he traced the path of the promised wound with his hook. It ran from groin to neck" (33).

As Candyman very reasonably points out, if Helen were to be slaughtered as yet another of his infamous victims, she would live forever as part of his legend, "in people's dreams." 3 Helen, however, resists what she recognizes as a "seduction," and instead states that she would "prefer to be forgotten than [to] be remembered like that" (33). But she has lied. She attends the complex's celebration of the bonfire night_-November 5 - already scheduled for that evening, a ritualistic reenactment of the foiling of Guy Fawkes" "Gunpowder Plot," and composed of cast-off furnishings from the complex rather than the gunpowder that Fawkes intended to use to blow up the English Parliament in 1605. By continuing to commemorate an event for which they have lost the meaning, the people of the housing project mirror Barker's sly presentation of Christians, who fail to grasp the horrific significance of their own ritualistic sacrifice of what was once a baby 
born in a precarious outpost. The baby in Barker's story mimics the baby Jesus, both sacrifices to social, economic, and political orders that they cannot redeem, even with their blood. But Helen is determined to play the role of savior herself, and she enters the bonfire in a futile attempt to rescue the already dead baby from burning to cinders in the flames. She fails and instead is taken deeper into the fire by the omnipresent Candyman: "perhaps they would remember her....Perhaps she might become, in time, a story with which to frighten children." Seeing her husband in the crowd, searching vainly for her, she muses that it would be lovely for him to see her burn and then she would have finally have something of value to give him "something to be haunted by. That, and a story to tell" (37). The story that Barker tells concerns not simply the taboo topics of castration anxiety, the fear of death, and the irrational desire for immortality - even if all of these topics are treated only as literary topoi. No, Barker is telling another, more cryptic and much darker tale, and it concerns the human need to invent divinities that embody our worst fears and imaginings. Candyman the stranger is somehow another version of Christ the redeemer, the super-human who holds out the promise of sweets but delivers instead only the stinking tomb. ${ }^{4}$

\section{III: "The emotional terrain of the slasher film is pretechnological." Carol Clover}

The first two filmic adaptations of Barker's story, both executively produced by Barker himself, accomplish different cultural work that his earlier story does not attempt. The American films transform the quasi-religious British Candyman into a black man, a victim of vicious racism himself and the subject of torture and murder, and it is this dichotomy between his victimization and his vicious treatment in turn of his victims, white women, that constitutes the urban legend at 
the heart of this sequence of texts. In the second film he is provided with a name, "Daniel Robataille," but his story is the same in both films (although the location of the events very noticeably changes from Chicago to New Orleans). The son of a former slave who becomes a successful designer of mass-produced shoes, Daniel is sent to the best schools and has been raised in polite society. His native talent as an artist is nurtured and he becomes so successful that he is hired by a prominent landowning family to paint the portrait of their beauteous white daughter. During the portrait sittings the inevitable occurs, and the woman becomes pregnant with the black man's child. Begging for permission to marry him, the daughter is forced instead to witness a white mob torture and mutilate the man. First, his right hand is chopped off and replaced with a hook, signifying his castration and ensuring his inability to ever paint again. The hook, of course, later becomes his murder weapon, as he attacks the bellies of his victims with one fell swoop and rips them open just as he had been eaten open by the bees. Next, his body is smeared with honey (hence the origins of his name) and then hundreds of bees are set loose to feed on his flesh. Once his body has been eaten away, he — an artist so sensitive to portraiture himself — is asked to look at his face in his beloved's mirror, to see reflected there his freakish monstrosity.

The mirror, as we might expect, comes to hold special powers, and as long as it remains in his possession his immortality is assured. Using a mirror in a film to signify the interconnection of narcissism, the gaze, and exhibitionism is not exactly original, but the mirror in this film finally represents something more; that is, it tropes the act of looking at and recognizing the undead history of racism and miscegenation in America. As their penultimate act of torture, however, the mob burns Daniel's body and scatters his ashes over the land that would eventually become the infamous Chicago housing project, Cabrini-Green. In the first Candyman film, Helen 
Lyle, a researcher attempting to document the persistence and cultural meanings of urban legends like the Candyman, finds herself drawn to the several competing versions of the tale, the popular versions told by students, janitors, and residents of the Cabrini Green housing project, as well as the professional versions told by her husband, sociology professor Trevor, and his professional rival, Archie. Hoping to synthesize all of these rival versions of reality into one overarching theme of meaning, Helen is very much the modern-day liberal mythographer, a contemporary Causabon, seeking the key to all mythologies, Joseph Campbell in drag. Helen begins her investigation certain of the non-existence of Candyman, for, as she tells a young boy in the housing development: ““Candyman isn’t real. He’s just a story, you know, like Dracula or Frankenstein. A bad man took his name so he could scare us, but now he's locked up, everything's going to be okay.",

Unfortunately, however, Candyman is real and what is even more alarming, he informs Helen that she is the reincarnation of his former white lover, the woman he has been waiting for on the site of his torture and murder. "“With my hook for a hand I'll split you from your groin to your gullet,"' Candyman's persistent refrain, echoes throughout the films as his horrific promise to link the reality of the body and its sexuality with the reality of death. As Hill notes, the legend is centered on the fact of the groin, while the legend is “also part of negotiating a woman's identity in response to heterosexual objectification" (171). Candyman is, for Hill, "a horror film in which the monster wins" (170). But does he? He loses his hook to Helen in the first film, and his mirror to Helen's replacement, Anne, in the second film. Women finally castrate the black man and seize the power that he had possessed, won by virtue of his intense sufferings and victimization. In winning the status of the privileged purveyor of the hook, the white woman 
rewrites the realities of American history and installs herself in the rightful position of both victim and victimizer. As such, the Candyman films invert the white liberal ideology of Barker's original story and present to the masses a more palatable fare: white liberal guilt is rewarded with the very real power to do something about discrimination. It is white women who seize the power to strike back, but they do not do so in a way that renounces racism; they do so instead in a manner that actually reifies racism.

The academic woman, forced to forego maternity in her manic pursuit of a career in the safe confines of the university, the ultimate patriarchal approval system, understands too late that women are finally bodies on which men (their husbands and colleagues and even the subjects of their research) can write only one script: seduction. When Trevor rejects Helen for a young student, an earlier version in fact of what Helen had been before she thought she could think for herself, he enacts the patriarchy's denunciation of the dangerous intellectual woman. So is it the blackness of Candyman that is figured as monstrously repressed, or is it the whiteness and intellectuality of the beleagured Helen? If women can function in ideological formations only as objects to be saved or punished, or exalted and fetishized, then what does this make of Helen? Very significantly, she has no child, nor is she likely to bear one given her husband's very blatant interest in other (and younger) women. Helen functions in the story as the ineffectual savior of the sacrificed baby, perhaps even the cause of the baby's death. In the first film version, however, Helen goes into the fire to bring the baby out alive, but she returns voluntarily in place of the baby and is consumed by the flames, a substitute sacrifice to Candyman's insatiable demands for more victims, more "sweets" to consume. Finally, Helen is coded as an intellectual, not a physical woman, and in the universe of male-created ideology, women cannot be both. As an intellectual, 
Helen is expendable; in fact, she is actually an anomaly that has to be eradicated if male hegemony is to be ensured. A woman without a fertilizable body can only stand as a threat, a potential castrator, a woman with a hook rather than a womb. Helen has to be eliminated because she can only be an empty signifier of the sterility and danger of the academic female.

But if Helen's whiteness and intellectual status have marked her for elimination, what does this mean for Candyman? Can he survive in her place, if, in fact, the white hegemonic system accepts her as the sacrifice? Another way of asking this question is to wonder, how can black men rewrite or recreate themselves in a culture that can only see them as sexual predators? And how do white women collaborate with black men in their own subjection and subjugation? The miscegenation as nausea theme, so prevalent in American culture, actually can be traced back to the gothic genre that originated and flourished in late eighteenth and early nineteenth century Britain. Dark men ravaging white women has been a staple of the gothic imagination, beginning with Matthew Lewis's presentation of the black slave Hassan in his gothic drama The Castle Spectre (1798) and culminating most notoriously in Charlotte Dacre's Zofloya (1804), a novel that depicts the seduction of a white woman by a black servant who is actually Satan in disguise. Samuel Arnold and John Fawcett's Obi, or the three fingered Jack (1800), was another popular British melodramatic work that depicts the social transgressions of a mutilated black Jamaican slave who leads an ill fated rebellion, while the play ends with the decapitation of Obi and the triumphant display of his head on the stage. Mary Shelley's Frankenstein (1818) presents a monstrous eight-foot tall man with yellow skin preying on men, women, and children indiscriminately, while Bram Stoker's Dracula (1897) concerns a Transylvanian aristocrat who sucks the blood from his 
preferred victims, women with very white skin. And their skin is a good deal whiter after the sucking. One need not look much further than the realities of British imperialism and its results to explain the intense anxiety that surrounded the association of black men and white women. In a culture where citizens were encouraged to travel and appropriate the goods and lands of other, darker peoples, one is forced to recognize that fairly quickly one of the unmistakable and unavoidable products of this travel was the appearance of mixed race children. Tremendous anxiety surrounded the existence of these children, and one might even be tempted to claim that the gothic functioned as a genre that brought the culture face to face with its worst imaginings: sexual relationships not between black women and white men, but between white women and black men. Preserving the pristine whiteness of British women — and by extension the British population — was the unstated goal of much of the cultural work of gothic fiction and later horror films. ${ }^{5}$

\section{III: Hysterics suffer mainly from reminiscences. -Freud}

In the second Candyman film adaptation, Candyman 2: Farewell to the Flesh (1995; director: Bill Condon), the action is moved to New Orleans, and in this version we are given much more graphic detail about the life and supposed crime of Candyman. As Barker himself explained, "the whole point of Candyman 2 is to enrich the mythology of the first film. I think it's going to end up more baroque than the first one; as much a consequence of locations than anything else. I think this movie will answer a lot of questions that were left

unanswered at the end of the first Candyman picture. ${ }^{6}$ In this second film we are literally 
shown the amputation of Candyman's hand, as well as the mob mutilation with the bees and a lynching added for good measure. We are also informed that Daniel Roboutille was murdered during the Mardi Gras celebration for his seduction and impregnation of Caroline Sullivan, recalling Christian associations with the crucifixion and penance. In fact, the reference to the ambivalent carnival atmosphere of Mardi Gras- the combination of licentiousness and abstinence-is invoked as the leitmotif of the film. Giving up the claims of the flesh is something that is impossible for all human beings, as the Candyman's ironic name implies. "Candyman," after all, could refer to the sugar cane that slaves harvested in the colonies, although its modern connotations refer to cocaine dealing, as well as a man guaranteed to deliver sexual satisfaction.

The viewer of this second film is given even more information about the black man in an effort to humanize him and position him as the true victim in the film, and this work culminates with Candyman demanding of the female gothic detective, Annie Tarrant, “"Be my witness." This is a significant shift and it suggests that the black male has moved from the subject to the object position. He can no longer victimize the woman, instead he can only ask her to actively record his sufferings and pain, to bear witness to his crucifixion and ultimate demise as the mirror, which had held the power of his immortality, cracks and he finally dies. Candyman 2, in fact, reveals how ideology triumphs as a representational system of repression, while also recuperating the anxieties of its purported audience. If the first Candyman film was suffused with racial fears and white ambivalence toward black encroachment on Northern cities, the second film comes down firmly on the side of liberal acceptance of miscegenation and the intermixing of the races. But notice that the action this 
time is set very firmly in New Orleans, about as southern an outpost as one can find in America.

Candyman 2 is predicated on the claim that Annie Tarrant is the descendent of Candyman, his great-great granddaughter. He has returned, not for revenge or wanton murder and sacrifice, but for recognition and acknowledgement by his "white" family. When Octavia, Annie's mother, refuses this act, she is killed with Candyman's infamous hook, while Annie is framed for the murder (a scenario that repeats the earlier framing of Helen for her black assistant's murder in the first film). Both films continually suggest the alliance of women and blacks, but finally both films refuse to do anything but present the association as monstrous, murderous, unnatural, and a manifestation of the horror-producing perverse. When Annie and Candyman have their final climactic confrontation, it occurs in the slave shanty behind the old plantation of the Sullivan family, the white enclave of power that had excluded and then murdered Daniel. His final plea, "'Be my witness,"” is a poignant statement of his longing for acceptance by a society that had written him out of their genetic record book. The monster is not, in fact, as monstrous as his white relatives, who have erased him and seek nothing more but to obliterate any rumor of his blood flowing in their veins. But the mirror that holds the magic of his immortality shatters, and he dies unaware that yet another descendant, a baby girl, will be born into his and Annie's family.

Candyman 2 concludes with Annie sitting in the bedroom of her very white and very blonde daughter, instructing the little girl that yes, she did once upon a time have a black man for a great-great-great-great-grandfather. It is all so long ago that the little girl, as well as her mother, can talk about the butchered Candyman as almost a fairy-tale figure, a distant 
and non-threatening detail of their lives. But after the mother leaves the room, the girl begins to conjure up Candyman in her mirror and the mother quickly appears, putting a stop to such potentially dangerous games. The film attempts, I think, to present an allegory of the hidden life of miscegenation in American society, but its dishonesty and its obsession with special effects and horror spectaculars ultimately detracts from what could have been a serious meditation on racism and sexism, and their unfortunate ideological marriage.

And setting the film in New Orleans is a particularly telling slip. Miscegenation in the South has long been an established fact of life, so the Sullivan clan's attempt to conceal Daniel's paternity of Caroline's daughter is farcical and pathetic, also ultimately doomed. But by first moving the action away from Liverpool, the bleakly industrialized England, to Chicago, the prosperously industrialized North, to New Orleans, the wanton, lustful capitol of sin in the South, reveals the dishonesty of the second film's vision. Whites in the rural South are allowed to cavort with blacks, but whites in industrialized areas are to be kept from contact with them. So "be my victim" can only be a threat in the North, where black migration from the South poses a very real threat to the more prosperous economy of white America. But "be my witness" is a far more palatable and safer statement, particularly in the South, where all the beleaguered Daniel wanted was to be acknowledged as part of a corrupt and ineffectual dying Southern family. The ideology that triumphs in the second film, as I noted at the beginning, is not positive, nor is it liberal. As an examination of this cycle of texts suggests, "sadism demands a story." And when that story is about black men and white women, the story can only be very sadistic indeed. 


\section{Doubling, Telegraphic Tags, and the Tortured Body: 'Gothika'}

In many ways, Gothika (dir. Mathieu Kassovitz and Thom Oliphant) is a postmodern revision of Charlotte Perkins Gilman's gothic classic The Yellow Wallpaper, as well as the most recent filmic heir to the Candyman series. Set in a New England high security prison for the criminally insane (reminiscent of the New England prison-like setting of Yellow Wallpaper), Gothika begins with a female psychiatrist, the biracial Miranda Grey, questioning a mental patient, the Latina Chloe, about her recurring rape fantasies: “'He came back again last night and tore me like paper. He opened me like a flower of pain and it felt good. He sank into me and set me on fire like he always does. Made me burn from the inside out." Chloe, clearly a hybridized double for Miranda (just as the nameless heroine of Yellow Wallpaper is doubled by the woman behind the wallpaper), is convinced that her rapist is "the devil," while the rationalist Miranda is determined to read her narrative as a memory of her earlier childhood sexual abuse at the hands of her stepfather (the man she later brags of murdering). Chloe's rapes while a patient in the prison, supposedly a safe haven, make her quite literally the embodiment of an "Anima Sola," a woman in flames, the tattooed figure that Miranda sees later on the back of her white rapist when she looks into Chloe's cell one night. The tattoo of the "Anima Sola" functions throughout the film as a visual code for the suffering, raped, tortured female body, and yet that image is tattooed on the white rapist's male torso, revealed at the end of the film to be a tortured palimpsest with slogans like "Life is Pain." 
But if Chloe is meant to be read as the woman in flames (tortured, abused), Miranda is initially presented as her opposite: rational, intellectual, removed from female suffering and abuse, and married to Dr. Douglas Grey, the powerful black psychiatrist who runs the asylum. When Miranda goes to his office to express her frustration at Chloe's continued complaints of rape within the asylum, he responds glibly, "'You have a brilliant mind. You'll figure it out. Throw [this water] on the mirror. This is what she sees now."' To which Miranda replies like a diligent school girl, "“A distorted image of herself."” Doug then asks her, "Who are you in all this?"” To which Miranda replies, "I'm the mirror....If I'm the mirror and she's the image, then who are you?" And Doug smugly asserts, "'I can see both of you so I am God....Always remember the ability to repress is actually a survivor tool, without it, Chloe may not have survived.'" So is the film about the repression of abuse as a survival mechanism, or does it concern the godlike powers that the strange mirror possesses, evocative of both the mirror in Candyman and the wallpaper in The Yellow Wallpaper? As we will learn by the end of the film, Doug as black male authority figure has violated the trust placed in him by becoming a sexually ravening monster, a man who pursues young white girls in order to rape, sexually torture, and murder them, all the while videotaping their victimization for his own later amusement. He is the "black buck" reincarnated, King Kong in human form, white society's worst imaginings about the potent black male seeking out white virgins to sacrifice to his lust. In the conclusion to this scene, when Dr. Peter Graham, the white psychiatrist with a patently obvious crush on Miranda, enters to speak to her, Doug offers him a large cigar and then ostentatiously cuts the tip of it. Recognized the phallic power of Doug in relation to his own impotence, Peter laughs, "“I just got circumcised."” But 
in fact the film will work, like Candyman, toward a real moment of castration when the powers of white authority and the female gothic detective collaborate to "circumcise" the black male.

The second doubling that occurs in the film is between Miranda and Rachel Parsons, a girl killed by Doug four years earlier. Rachel appears one rain-swept night on a bridge in "half-light" (a liminal locale), bursts into flames, and takes possession of Miranda's body. While possessed by this second woman in flames, Miranda returns home and kills Doug. Scrawled on the wall outside their bedroom in Doug's blood are the words, "NOT ALONE," which work throughout the film much like the telegraphic tagline "Sweets to the Sweet" functioned in Candyman. Miranda wakes up to find herself an inmate in her own former place of employment and she has no memory of having committed the murder, nor does she understand the meaning of the words "not alone," which are mysteriously written on her flesh and later on the glass of her prison cell.

From this point on, Miranda becomes the female gothic detective, determined to discover the true murderer of her husband. Like a female Oedipus, however, she is forced eventually to recognize herself as that murderer and by doing so she allies herself with the other women in flames that she had earlier treated as psychotics. In the common room scene we can see most clearly how Miranda has now become like the woman behind the yellow wallpaper when Chloe approaches her and says, “'You're one of us now.... You're invisible now. Are you scared?... You should be."” And her threat proves true when in the shower scene Miranda emerges with the words "NOT ALONE" crudely carved on her arm. 
These words become her first clue, and Miranda's initial interpretation of their meaning lead her to conclude, as she says to Dr. Philip Parsons, "“I wasn't there [at the murder scene] alone and that's what 'not alone' means."' True, but initial interpretations are most frequently partial, and Rachel's ghost leads Miranda to a fuller understanding of those words, letting her out of her prison cell and on the road to the ultimate scene of the crime: Doug's lair at Willow Creek, a den of sexual perversion and videotape equipment. Before arriving there, however, Rachel directs Miranda's car to the home she so naively shared with Doug for the first set of clues. Her search leads to their marriage bed and her discovery of a picture taken in earlier happy times at the farm at Willow Creek. When Rachel mysteriously causes blood to drop on that picture, Miranda has her next clue and she heads to the farm, finally discovering in the basement of the barn the true identity of her husband and his close friend Sheriff Robert Ryan. The marital bed that Miranda had mused on moments earlier is now darkly doubled by the basement bed, scene of so much sexual torture and voyeurism, complete with blood stained sheets and a drug cabinet filled with sedatives to better dominate his victims.

When Miranda examines the last videotape in the machine she sees the face of her husband preening in the camera and bragging, "'It's good to be God. I love you."” This monomaniacal statement eerily duplicates the first scene in the film, when Doug had told Miranda that he was "god" because he was able to "see" both her and Chloe in the mirror. Clearly his sense of divinity was based on his power to sexually possess both women while neither understood that the other was also his sex slave. When yet another victim emerges from under the stairwell, Miranda thinks that she finally understands the message that Rachel has been 
trying to convey: "'That=s what NOT ALONE means, Rachel was trying to tell me that she was not the only victim."”

But no, this second interpretation is still not enough, because Doug has not been the only abuser and murderer. When Miranda finds herself in the local police station, she begins to realize that Doug has had an accomplice, the white sheriff: "It's your classic mentor and disciple syndrome, that's what NOT ALONE means." Forced to conduct a very quick psychological profile of Ryan, she concludes that he fits the disciple role perfectly: "Absent father, overly obsessive relationship with mother, animal torture, confused about his sexuality as an adult." And Ryan himself admits the crimes as if he were talking about preferences in food, "'You never lose your taste for the young girls." His is the last body to be consumed in flames as his tattooed torso, literally covered in tag lines and images of abuse and suffering, goes up in fire in his own police station. The film concludes with Miranda trying to save the ghost of missing child in a city street, reminiscent of Helen's attempt to save the sacrificial baby at the conclusion of Candyman. But this nod to the threat of child abuse is not ultimately what the film has attempted to explore.

The female gothic detective has not only discovered that her husband, a black male, was a ravening sexual monster, but that he was propped up in his perversions by the white male authority structure of the police. Such a realization recalls the dark discoveries of Ann Radcliffe's heroines, who frequently learned that the corrupt duke had been supported in his murderous intrigues by the local abbot or a duplicitous or lecherous monk. The female gothic detective traditionally comes to the unhappy conclusion that the entire patriarchal system (the state, the church, social institutions) is corrupt and based on the consumption and eradication of 
vulnerable and expendable female bodies. Whereas racial differences figured predominantly in the Candyman films, the race issue is hybridized in Gothika, and the black male is portrayed as just as evil as any white man in the film's universe. But where cultural critics like Homi Bhabha would like us to see "hybridization" as a more accurate depiction of just how complex the issue of race has become in a postcolonial world, one is forced to wonder after viewing this film if it does not present us with yet another cultural manifestation of racist fears about the "big black buck."

\section{NOTES}

1 See Schneider, Wartenberg, and Modleski for discussions of "mixed-race couples," King Kong, and race in contemporary films, in particular Candyman.

2 Revisions of Mulvey's essay are numerous, and include de Lauretis, Doane, and Mulvey herself (1988).

3 As Barker himself noted, in talking about the first film version of the Candyman character, “He's very sympathetic. And there's a great seduction to him. He invites his victims. He's quite polite about it: 'Be my victim.' Of course he pursues them relentlessly and of course he's going to get what he wants. He's probably more like Dracula than any other monster: he does seduce, and he does offer a kind of immortality, which is what Dracula does. He says, 'Be part of my legend.' And what Dracula says is, 'Allow me to bite you and live forever.' But yes, I think the appeal is definitely one of immortality." (Barker quoted in "Clive Barker's Candyman 2,"

Cinefantastique 26 [1995], 9).

4 A somewhat similar conclusion has been reached by Hoppenstand, who reads the Spector 
Street graffiti as "the religious language of a new god, a god born from folklore legend, a god who accepts sacrifices of blood and candy, a god emblematic of the contemporary urban experience....The Candyman's stock-in-trade is true immortality, an immortality that sacrifices the physical body in favor of notoriety, an immortality powered by the oral tradition of legend that is part of the same life force that animates the dreaded Candyman himself" (135).

${ }^{5}$ For a sample of the very diverse and interesting approaches to the Candyman films, see Briefel and Ngai, Botting, Halberstam, and Wyrick.

${ }^{6}$ Interview with Clive Barker in "Candyman: Interview with the Monster," Cinefantastique $26(1995), 43$.

\section{WORKS CITED}

Barker, Clive. The Forbidden, in Books of Blood, volume five (London: Weidenfeld \& Nicolson, 1985), 1-37.

Bhabha, Homi. "Of Mimicry and Man: The Ambivalence of Colonial Discourse." October 28 (1984), 126-32.

Botting, Fred. "Candygothic.” In The Gothic. Ed. Fred Botting. Cambridge: Brewer, 2001. 13351.

Briefel, Aviva, and Sianne Ngai, “'How much did you pay for this place?’: Fear, Entitlement, and Urban Space in Bernard Rose’s Candyman,” Camera Obscura 37 (1996), 71-91.

Candyman. Dir. Bernard Rose. Written by Bernard Rose. 1992.

Candyman 2: Farewell to the Flesh. Dir. Bill Condon. Written by Rand Ravich and Mark Kruger. 1995. 
Clover, Carol. Men, Women, and Chain Saws: Gender in the Modern Horror Film. Princeton: Princeton U P, 1992.

de Lauretis, Teresa. Alice Doesn't: Feminism, Semiotics, Cinema. Bloomington: Indiana University Press, 1984.

Doane, Mary Ann. "Film and the Masquerade: Theorizing the Female Spectator." Screen 23 (1982), 74-88.

--“Masquerade Reconsidered: Further Thoughts on the Female Spectator.” Discourse 11 (1988-89), 42-54.

Gothika. Dir. Matthieu Kassovitz. Written by Sebastian Gutierrez. 2003.

Halberstam, Judith. Skin Shows: Gothic Horror and the Technology of Monsters. Durham: Duke University Press, 1995.

Hill, Mike. “Can Whiteness Speak: Institutional Anomies, Ontological Disasters, and Three Hollywood Films.” In White Trash: Race and Class in America. Ed. Matt Wray and Annalee Newitz. New York: Routledge, 1997, 155-76.

Hoppenstand, Gary. Clive Barker's Short Stories. Jefferson, NC: McFarland, 1994.

Modleski, Tania. "Cinema and the Dark Continent: Race and Gender in Popular Film." In Feminism Without Women: Culture and Criticism in a 'Postfeminist' Age. New York: Routledge, 1991.

Mulvey, Laura. “Afterthoughts on 'Visual Pleasure' Inspired by Duel in the Sun." In Feminism and Film Theory. Ed. Constance Penley. NewYork: Routledge, 1988.

-----------. "Visual Pleasure and Narrative Cinema.” Rpt. Feminisms. Ed. Robyn R.Warhol and Diane Price Herndl. New Brunswick, NJ: Rutgers U P, 1991, 432-42. 
Schneider, Steven Jay. "Mixed Blood Couples: Monsters and Miscegenation in U.S. Horror Cinema.” In The Gothic Other. Ed. Ruth B. Anolik and Douglas Howard. Jefferson, NC: McFarland, 2004.

Wartenberg, Thomas E. "Humanizing the Beast: King Kong and the Representation of Black Male Sexuality.” In Classic Hollywood, Classic Whiteness. Ed. Daniel Bernardi. Minneapolis: U of Minnesota P, 2001. 157-77.

Williams, Linda. "When the Woman Looks." In Re-Visions: Essays in Feminist Film Criticism. Ed. Linda Williams, Mary Ann Doane, and Patricia Mellencamp. Frederick, Md: University Publications of America and the American Film Institute, 1986.

Wyrick, Laura. "Summoning Candyman: The Cultural Production of History." Arizona Quarterly 54 (1998), 89-117. 